\title{
LA NEGOCIACIÓN, UN FACTOR IMPORTANTE
}

\author{
Por: Ing. Edgar Miguel Hernández $\boldsymbol{H}$.
} Docente IMA.

Con la situación que vive nuestro mundo se hace necesario que todos manejemos algunos aspectos elementales de la negociación, para lo cual ante todo debemos pensar qué es la negociación: podemos decir que ésta es un intercambio en el cual cada parte ofrece algo que tiene y la otra necesita ó desea.

A partir de este sencillo concepto podemos estructurar toda nuestra metodología para negociar. ¿Quiénes negociamos? Todos absolutamente todos, gobiernos y habitantes, padres e hijos, esposos, jefes y subalternos, directivos y dirigidos, empresarios y empleados, mendigos y pudientes, reyes y súbditos, en fin, todos nosotros.

¿Qué negociamos? De todo: alimentos, sueldos, cariño, compañía, artículos de consumo, tasas de interés etc, cada cosa tangible o intangible que tengamos o deseemos es negociable.

¿Para qué negociamos? Sencillamente para satisfacer una necesidad, y aquí aparece una diferencia entre nosotros y es que cada uno persigue cosas diferentes; nuestra mente y nuestro cuerpo desean cosas en mayor ó menor grado diferentes a las que quiere otra persona, y cuando escribo cuerpo es completo: cuerpo y alma, carne y espíritu, mente y físico.

Nuestra estrategia de negociación entonces está muy ligada a nosotros; cumplimos bien nuestro deber pues deseamos llevar comodidad a los nuestros por medio de los dineros que recibi-



mos como retribución a nuestro esfuerzo, nos preparamos para poder ascender en la escala jerárquica de nuestro trabajo o al menos para mantenernos en él, cuidamos a nuestros amigos ya que sabemos que también los necesitamos y esperamos que nos ayuden, nos acompañen, nos alienten, compartan o no nuestros mismos ideales, pero esa amistad es un negocio; te conozco y comparto algo contigo y tú me conoces y compartes conmigo.

A veces no es fácil pensar en nuestras relaciones personales como negocio, pero no perdamos de vista este concepto para poder aplicar estrategias probadas que sirven en este campo para obtener resultados; seguramente más de una vez hemos intentado definir nuestras relaciones como intercambios libres, espontáneos y despreocupados de toda retribución, pero ésto no es cierto; difícilmente lo entenderemos si pensamos en situaciones en las cuales no necesitamos nada, al contrario, pensemos en aquellas ocasiones en las cuales una mano amiga nos ha ayudado, una mano cariñosa nos ha protegido, una mano se nos ha ofrecido.

Nosotros y todos quienes nos rodeen debemos pensar que compartimos este mundo y no tenemos otro; debemos ayudarnos y buscar entre todos el bienestar y la mejor forma de cumplir nuestra misión en el mundo.

Por esto enseñemos a nuestros relacionados que el mejor negocio es dar para así poder recibir; los resultados de toda negociación son: Ganar - Perder, Perder - Perder, Peder - Ganar, Cero resultados, y la más conveniente para todos, Ganar - Ganar; esta última debe ser siempre nuestra guía, hacer cuanto esté a nuestro alcance para que tanto nosotros como la contraparte estemos en ganancia, sin olvidar que esta negociación debe ser recíproca. No podemos pretender ganar ganar, si todos los involucrados no lo deseamos.

Siempre nuestra actuación deber ser ejemplar; debe responder a la búsqueda de un progreso $y$ un estado satisfactorio para todos, permitiendo el uso de la libertad de elección para estar mejor sabiendo que nuestras decisiones afectan de alguna forma a otras personas; así que nuestra meta ha de ser una decisión digna de nuestro ser y de nuestro parecer, que nos comprometa con un futuro del cual somos los armadores y actores; pidamos menos y demos mas; así lograremos generar un cultura mejor para todos. 